\title{
Exploring drivers and deterrents of the illegal consumption and trade of marine turtle products in Cape Verde, and implications for conservation planning
}

\author{
Joana M. Hancock, Safiro Furtado, Sonia Merino \\ BRENDAN J. GODLEY and ANA NUNO
}

\begin{abstract}
Conservation regulations aimed at restricting resource use are commonly used to manage and protect natural resources but their implementation depends on the compliance of resource users. The design of effective regulations should be informed by an understanding of the factors that affect compliance, considering contextual socio-economic information. Changes have been implemented in the national legislation protecting marine turtles in the Cape Verde archipelago, where historical and recent records indicate heavy human predation pressure on nesting and foraging marine turtles. We present an assessment of levels of illegal harvesting and consumption of marine turtle products on two of the islands, Boa Vista and Santiago, and an analysis of their potential drivers. Key stakeholders were interviewed to investigate the perceived impact of the main interventions employed in Cape Verde to reduce illegal harvesting, trade and consumption of marine turtles. Despite an apparent decrease in harvesting and consumption, our results suggest there has been a shift from subsistence harvesting to trade in Boa Vista. The existence of laws to protect marine turtles was perceived as a deterrent to harvesting, and awareness campaigns and a lack of availability were perceived as reasons for the decrease in consumption in Boa Vista and Santiago, respectively. Aiming to inform ongoing discussions, we recommend a multi-targeted approach focusing on both suppliers and consumers to magnify conservation effectiveness. Regular impact evaluation focusing on harvest and consumption is needed to improve the design of regulations and inform policy decision making.
\end{abstract}

JoANA M. HanCOCK ${ }^{*}$ (Corresponding author), BRENDAN J. Godley and ANA NunO Centre for Ecology and Conservation, College of Life and Environmental Sciences, University of Exeter Cornwall Campus, Penryn, Cornwall, TR10 9EZ, UK. E-mail joana.hancock@gmail.com

SAFiro Furtado $\dagger$ Turtle Foundation, Boa Vista, Cape Verde

Sonia Merino Dirección Nacional de Investigación en Ciencia, Tecnología e Innovación, Plan Maestro, Centro de Gobierno, San Salvador, El Salvador

${ }^{*}$ Also at: Turtle Foundation, P.O. Box 172, Sal Rei, Boa Vista, Cape Verde, and Centre for Ecology, Evolution and Environmental Changes, Faculdade de Ciências da Universidade de Lisboa, Edifício C2, $5^{\circ}$ Piso, Sala 2.5.46 Campo Grande, 1749-016 Lisbon, Portugal

$\dagger$ Deceased 16 July 2012

Received 1 September 2015. Revision requested 3 November 2015.

Accepted 19 January 2016. First published online 12 May 2016.
Keywords Cape Verde, coastal livelihoods, illegal harvest, law enforcement, loggerhead turtle, wildlife trade

To view supplementary material for this article, please visit http://dx.doi.org/10.1017/So030605316000107

\section{Introduction}

Cor millennia people have preyed upon marine mega- fauna and benefited from their use, incorporating them into their livelihoods and cultures (Jackson et al., 2001; Witherington \& Frazer, 2003). However, there is a modern tendency for people to overexploit such resources (Parsons, 1962; Nietschmann, 1995; Springer et al., 2003), and shifts from subsistence use to the commercial exploitation of marine wildlife stocks have led to the local or global extinction of many species, and declines of others (Baum et al., 2003; Polidoro et al., 2008).

Challenges in conservation implementation are diverse and are often related to the social-ecological nature of the systems in which interventions occur (Pollnac et al., 2010; Nuno et al., 2014); for example, conservation agreements and legislation aimed at restricting resource use (e.g. harvest quotas, protected areas and harvest seasons) are commonly used to manage and protect natural resources but their successful implementation depends on the compliance of resource users (Keane et al., 2008). Conservation programmes often lack a robust understanding of the socioeconomic context and decision-making processes affecting resource use, which is essential for assessing the feasibility of potential management strategies and implementing effective interventions (Roe et al., 2002; St. John et al., 2013; Raymond \& Knight, 2013), such as through law enforcement (Rowcliffe et al., 2004). In addition, this knowledge should be coupled with regular scientific assessment and potential adjustments (Pullin et al., 2004; Sutherland et al., 2004; Garnett et al., 2007) to inform policy makers about the effectiveness of ongoing interventions and aid them in identifying alternatives.

In the Cape Verde Islands, in the Atlantic Ocean, historical records and recent studies suggest heavy human predation pressure on nesting and foraging turtles on most islands (López-Jurado, 2007; Loureiro \& Torrão, 2008; 


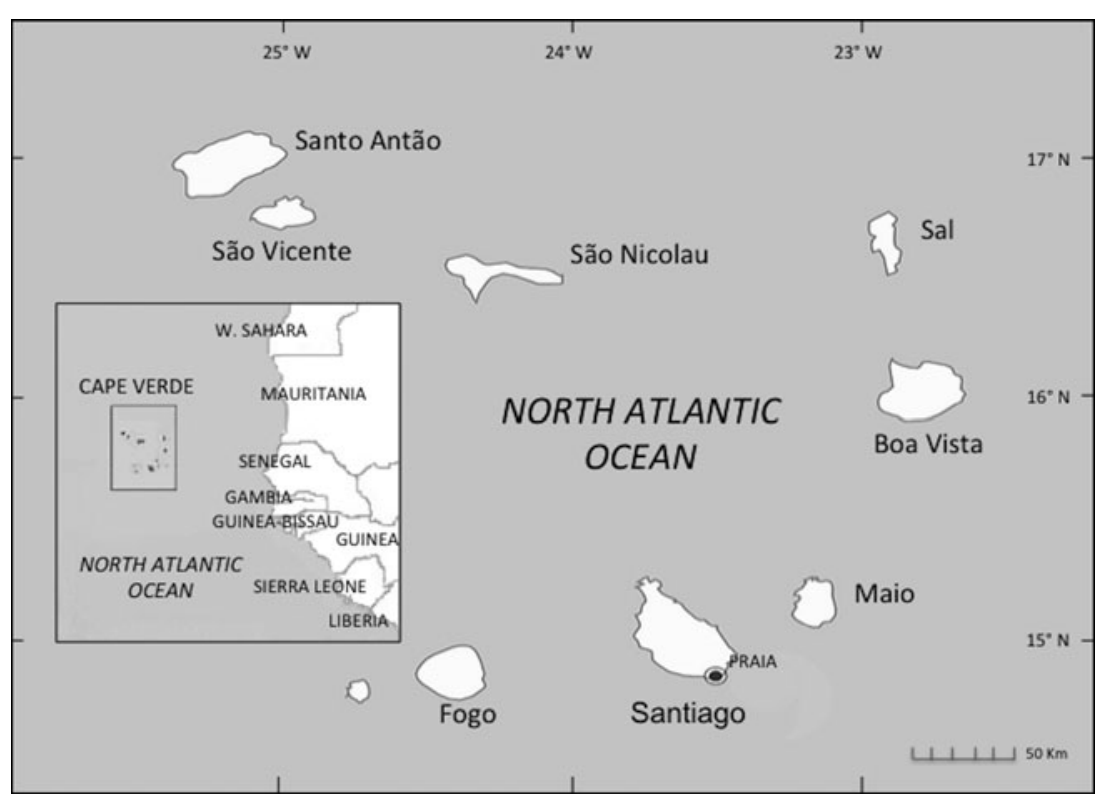

Fig. 1 The Cape Verde Archipelago, where the illegal consumption and trade of marine turtles was studied on the islands of Santiago and Boa Vista.
Marco et al., 2012; C. Roder, Programme Director of Turtle Foundation, pers. comm., 15 July 2015). This is despite several conservation interventions, including the implementation of national legal frameworks that penalize the killing and consumption of marine turtles (Boletim Oficial da República de Cabo Verde, 2005, 2010), military enforcement of marine turtle protection on the main nesting beaches, and public awareness activities led by local and international NGOs. In December 2015 environmental authorities approved a new decree to reinforce the existing law, making marine turtle harvesting a matter for the criminal, rather than the civil, procedure code. As a result, custodial sentences can be imposed on those convicted of the intentional capture, detention or killing of marine turtles, or the purchase and sale of live or dead turtles and their by-products. The consumption of meat, eggs or any byproducts is also subject to judicial convictions. However, a lack of socio-economic data and limited information on the prevalence of harvesting and consumption of turtles may undermine the robustness of policy decisions and challenge the implementation of effective regulation in the study area.

We aimed to explore the dynamics of the harvesting, consumption and trade of marine turtles and their products in Cape Verde in response to conservation efforts and the implementation of legal protection of marine turtles. Firstly, we assessed levels of harvesting and consumption of marine turtle products, and explored what socio-demographic and economic factors potentially affected their trade and consumption. Secondly, we investigated the perceived effectiveness of two broad categories of interventions that have been employed, individually or in combination, in Cape Verde to reduce the harvesting, trade and consumption of marine turtles:
(1) establishment of regulations and law enforcement, and (2) campaigns to increase awareness (Supplementary Table $\mathrm{S}_{1}$ ). Ultimately we aimed to inform ongoing discussions about marine turtle protection in the study area, and recommend the need for a better understanding of contextual factors for the design of effective conservation regulations.

\section{Study area}

Cape Verde is a small insular country c. $500 \mathrm{~km}$ from the west coast of Africa, with a population of c. 491,00o inhabitants and a mean gross domestic product of USD 1,865 per capita in 2011 (The World Bank, 2012). The country is characterized by a young population, distributed unequally among the nine inhabited islands, with c. 50\% of the population inhabiting the main island, Santiago. Since 1950 the population has increased by $82 \%$, with increases particularly notable in urban centres, such as the capital city, Praia, on the island of Santiago (World Health Organization, 2010). On Boa Vista, the main tourism destination, the population has tripled since 1990 (INE, 2010).

Cape Verde is believed to be the third most important known nesting site for the loggerhead turtle Caretta caretta and it is estimated that $85-90 \%$ of turtle nesting in the country occurs on the beaches of Boa Vista (Marco et al., 2011). This study focused on the islands of Boa Vista and Santiago (Fig. 1).

\section{Methods}

During May-June 2011, 147 and 291 interviews were conducted with individuals in the main coastal communities 
of Boa Vista and Santiago, respectively. The study locations were selected based on preliminary information obtained from fishers who were formerly involved in harvesting marine turtles, which was used to identify areas of high consumption of turtles or where turtle harvesters and sellers were known to be present. The sample size of each target group (i.e. on each of the islands) was defined using a power analysis for a normal approximation to the exact binomial distribution, based on the number of registered fishers and fish sellers, as well as the adult population, on both islands ( $95 \%$ confidence level, with $5 \%$ confidence interval and 50\% expected effect size because of a lack of baseline information). Past and current harvesters and sellers were selected through snowball sampling to assess the dynamics of the harvesting and trade. Artisanal fishers $(\mathrm{n}=128)$ and fish sellers $(\mathrm{n}=23)$ from both islands were interviewed at landing docks, beaches and markets, or found through lists of names provided by the local fishers' associations. Convenience sampling was used to select members of the public for interviews on the streets of the main urban centres on each island ( $\mathrm{n}=95$ in Boa Vista; $\mathrm{n}=190$ in Santiago), with the objective of obtaining information on general consumption patterns and attitudes (the characterization of the main target groups is summarized in Supplementary Table S2).

The surveys included both open and closed questions about (1) socio-economic and demographic characteristics; (2) present and past participation in harvesting, sale or consumption of marine turtles, and potential drivers of these activities; and (3) perceptions and awareness of marine turtle conservation (Supplementary Material 1). Questions were designed to assess respondents' perceptions of how harvesting, sale and consumption had evolved. The survey also involved mapping trade dynamics, including identification of the main trade chain parameters, particularly sources and sinks of turtle meat, sale locations, species traded and product prices. A shorter version of the survey, including only the sections related to consumption patterns and perceptions, was used for the general public (Supplementary Material 1).

Data analysis and statistical tests were conducted using $R$ v. 2.9.1 (R Development Core Team, 2009). We used $\chi^{2}$ tests to test for significant associations between variables, and paired t-tests to compare non-independent past and present behaviour prevalence.

This study complied with the laws of Cape Verde, and research was conducted according to the University of Exeter research ethics policy and was approved by the University Ethics Committee. Given the sensitive and illegal nature of turtle harvesting in the study area, interviewees were assured that all information would be recorded anonymously and that participation was voluntary and they could choose not to answer individual questions.

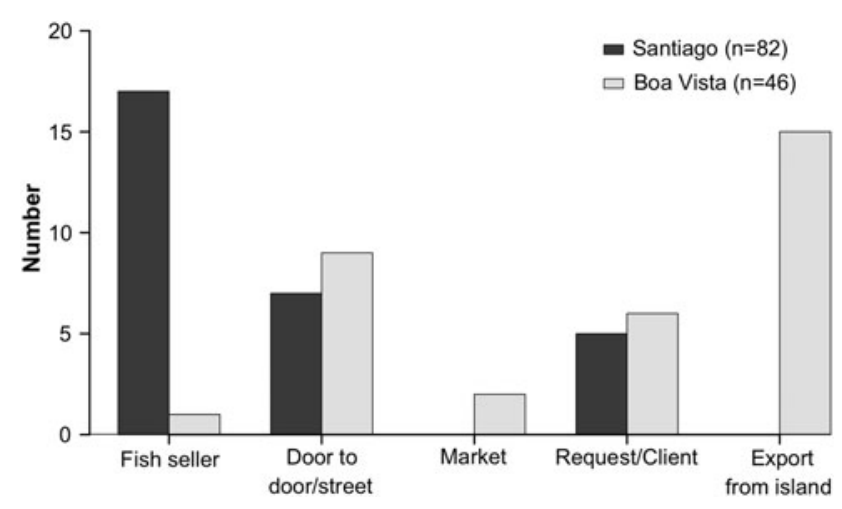

FIg. 2 The number of active turtle fishers on Santiago and Boa Vista (Fig. 1) who reported each type of primary sink for harvested marine turtles.

\section{Results}

\section{Harvesting and trade of marine turtles in Cape Verde}

Our results indicated that harvesting of marine turtles in Cape Verde was generally carried out by fishers, and sale of turtle products was mostly done by fish sellers (a job predominantly done by women). Fish sellers also served as the main intermediary between the harvester and the consumer, although fishers also sold turtle meat door-to-door or directly at the landing site (Fig. 2). We identified 28 fishers who were active harvesters, and five fish sellers who were actively engaged in the sale of turtle meat, representing c. $22 \%$ of each of these groups. Based on this selfreported information obtained from surveyed fishers, which potentially underestimates their involvement in these behaviours, from 2002 to 2011 the estimated percentage of our sample involved in harvesting marine turtles decreased from 61 to $17 \%$ in Boa Vista (95\% CI 28.6-58.4), and from 87 to $18 \%$ in Santiago (95\% CI 60.2-80.5) (Fig. 3). Meanwhile, during the same period the percentage of fish sellers involved in the sale of marine turtle products remained stable in Boa Vista (only one of the interviewed fish sellers ever engaged in sale of turtle products, but remained active) and decreased from 78 to $22 \%$ in Santiago (95\% CI 39.4-90.0).

Despite this apparent decrease in the number of active harvesters and sellers, typical annual capture rates at the time of the study varied, reported as low (1-3 turtles per year) by 11 fishers (48\%), medium (3-10 turtles per year) by 7 fishers $(30 \%)$ and high (10 turtles or more per year) by only one fisher ( $4 \%$ ); the remaining nine active harvesters did not disclose this information. Based on the capture rates reported by the 19 fishers that provided this information, we estimate an annual harvest of at least 50-114 turtles (20-52 by fishers from Boa Vista; 30-62 by fishers from Santiago).

According to the information provided by the active harvesters the majority of the turtles were caught at sea ( $74 \%$ of 


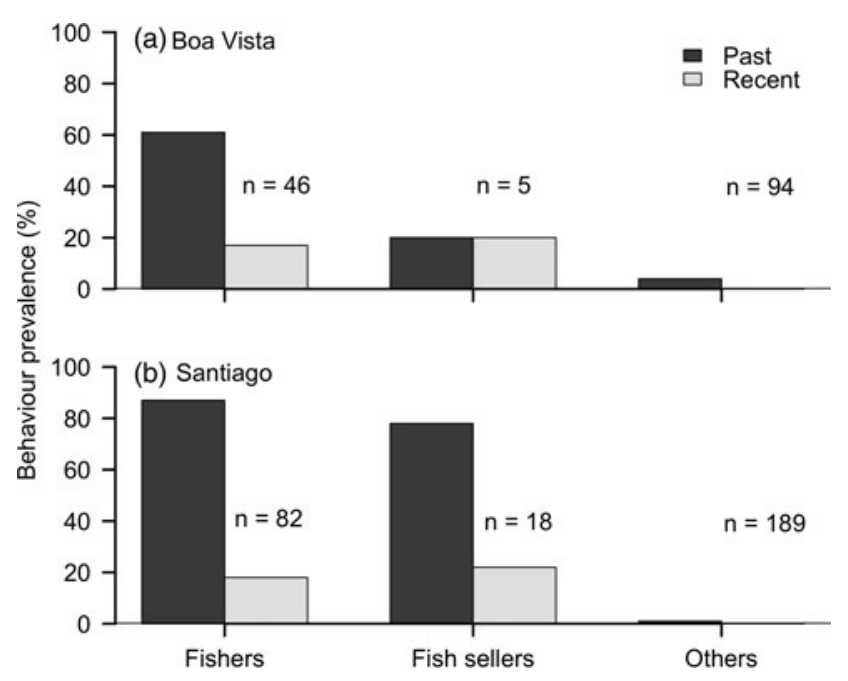

FIG. 3 Self-reported past and recent involvement in harvesting marine turtles by fishers and the general public (Others, excluding fishers and fish sellers), and sale of turtle products by fish sellers on (a) Boa Vista and (b) Santiago (Fig. 1).

respondents; 7 on Boa Vista and 15 on Santiago) and some were caught on the nesting beaches ( $29 \%$ of respondents; 1 on Boa Vista and 8 on Santiago; both options were given in the question). Marine captures by Boa Vista fishers were all in local, insular waters, whereas fishers on Santiago harvested turtles in the waters surrounding a variety of islands, mainly Boa Vista, Maio and Santiago. The beaches where captures took place were not identified but all were local to the fishers' island of origin.

The information gathered from the interviews suggests that the typical trade chain varied between islands. On Santiago the majority of the fishers that actively harvested marine turtles chose to have fish sellers as intermediaries between them and the consumers $(n=18)$, thus creating a trade, although some stated that they had a well-established list of regular customers $(n=5)$. In Boa Vista only one of the five known fish sellers was actively involved in the sale of turtle meat (Fig. 3).

Typical products traded in Cape Verde that were recorded in this study include whole turtles, turtle meat, eggs and penises. The price of live adult turtles was significantly higher on Santiago, whereas the value of other turtle products was found to be similar on both islands (Supplementary Table $S_{3}$ ). According to the fish sellers interviewed, prices were determined by turtle size rather than seasonal availability, species or the risk associated with the sale.

\section{Consumption of marine turtles}

Based on all interviews (including among the general public), the consumption of marine turtle products on both islands has decreased since 2002, with a reduction of $62 \%$ on Santiago (95\% CI 56.7-67.9) and $28 \%$ on Boa Vista (95\% CI

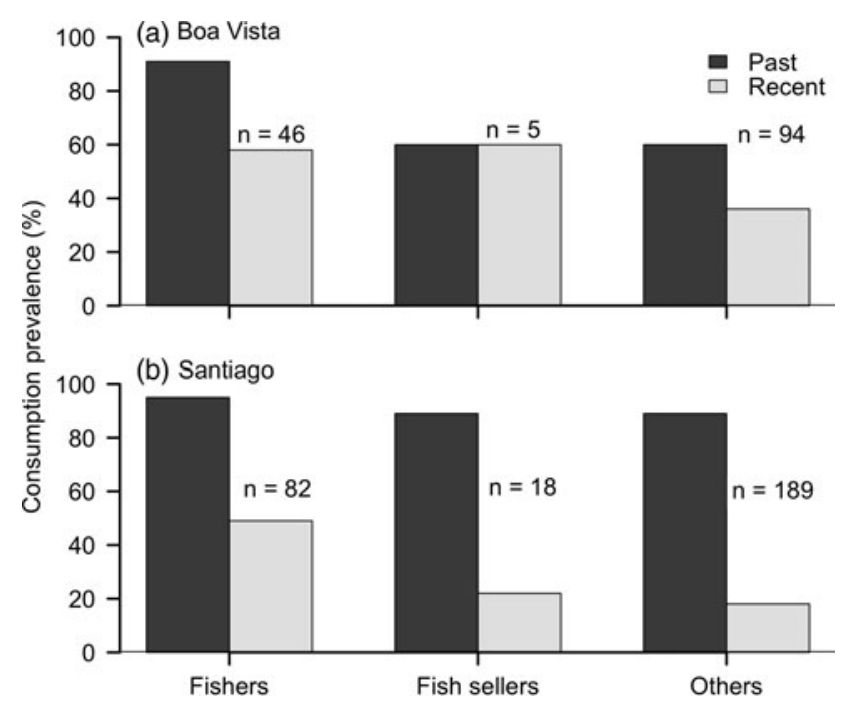

FIG. 4 Self-reported past and recent consumption of marine turtle products by fishers, fish sellers and the general public (Others) on (a) Boa Vista and (b) Santiago (Fig. 1).

20.9-35.7; Fig. 4). Consumption was found to be unrelated to age, income or occupation $(\mathrm{P}>0.05)$ but those with lower educational levels were more likely to consume turtle products $\left(\chi^{2}=10.74, \mathrm{df}=4, \mathrm{P}=0.03\right)$. There was a significant difference in present consumption between the islands $(z=3, \mathrm{P}=0.003)$, with a higher proportion of the population on Boa Vista consuming turtle than on Santiago.

\section{Self-reported drivers of trade and consumption}

According to survey respondents the prevalence of commercial use of multiple types of turtle meat has increased on Boa Vista since $2002(z=-2.44, \mathrm{P}=0.01)$, suggesting that there was a shift to harvesting primarily for trade with Santiago (Fig. 5), conducted mainly by natives of Santiago ( 5 of the 9 active turtle fishers identified on Boa Vista).

Traditionally, turtle harvesting was not considered a primary source of income on either island $(\mathrm{P}>0.05)$ but the supplementary income from the sale of turtles was considered to be more important on Santiago than on Boa Vista $\left(\chi^{2}=12.98, \mathrm{df}=4, \mathrm{P}=0.01\right)$, where the mean monthly income was considerably lower $\left(\chi^{2}=10.63, \mathrm{df}=4\right.$, $\mathrm{P}=0.003)$. In general, turtles were harvested mostly opportunistically ( $85 \%$ of all fishers surveyed, regardless of island, $P>0.05$ ), generally to meet extra expenses related to boat fuel or food when fish supplies or associated income were low (especially on Santiago). Fishers and fish sellers who had never been, or had ceased to be, engaged in the harvesting and sale of marine turtles indicated that the existence of legislation was the main deterrent (Fig. 6).

The main self-reported drivers for respondents to stop or avoid the consumption of marine turtle meat varied between the two islands $\left(\chi^{2}=87.81, \mathrm{df}=4, \mathrm{P}<0.001\right)$, with environmental awareness playing an important role on Boa 


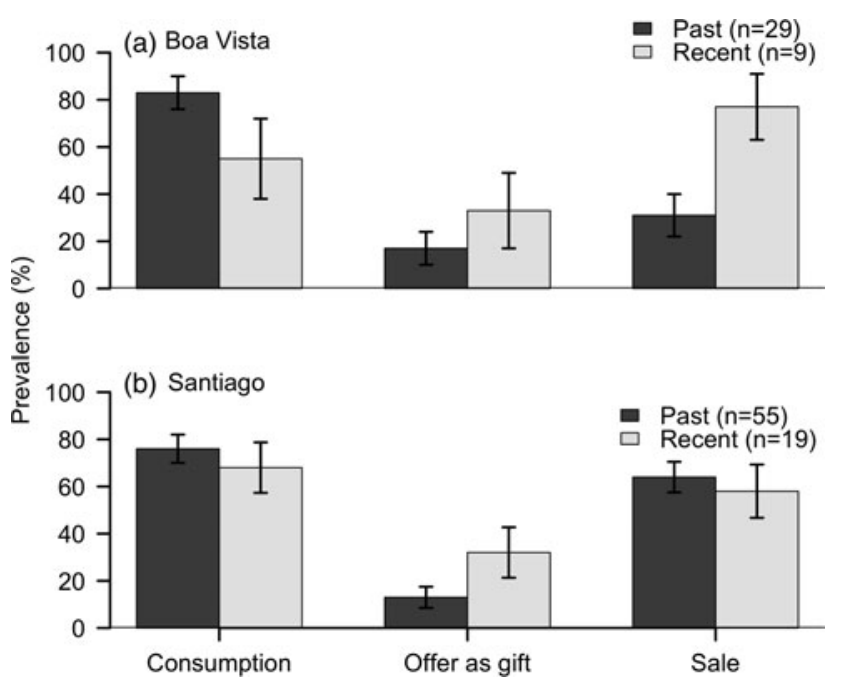

FIG. 5 Past and recent uses of marine turtles by fishers on (a) Boa Vista and (b) Santiago (Fig. 1), suggesting a shift to commercial use on Boa Vista.

Vista, where several NGOs have been carrying out environmental education and public outreach. The low availability of turtle meat for sale on both islands and the elimination of the main points of sale by law enforcement agents in Praia have apparently driven the decrease in the level of consumption (Fig. 6). Taste was also a deterrent for some consumers.

\section{Law enforcement and legislation}

The self-reported level of awareness about conservation and the importance of marine turtles was high on both islands, suggesting that in general the population had a positive attitude towards turtles and supported their protection (Supplementary Table $\mathrm{S}_{4}$ ). Existing laws were perceived as being effective by more respondents on Santiago (68\%) than on Boa Vista (50\%). However, respondents reported a perceived lack of law enforcement (90\%) and insufficient protection at the beaches and docks $(92 \%)$ as the main reasons why the trade in marine turtles continues. Increased awareness about turtle conservation has not necessarily resulted in a change in consumptive behaviour, as respondents often contradicted themselves by openly admitting to supporting and participating in the consumption of turtle meat, ignoring the fact that this is also prohibited by law (only $9 \%$ of respondents knew that consuming marine turtle meat was prohibited). Nevertheless, $94 \%$ of all respondents knew that harvesting of marine turtles was prohibited.

\section{Discussion}

\section{Illegal harvest and consumption}

Despite a decade of targeted interventions our results indicate that, at the time of the study, illegal harvesting of marine turtles persisted on nesting beaches and in the waters surrounding both islands. This confirms suggestions from anecdotal evidence and previous studies in the area (Cozens et al., 2012; Marco et al., 2012). However, our findings indicated there had been a reduction in the levels of harvesting and consumption over time, possibly as a result of the protective law introduced in 2002, although the magnitude of the reduction must be regarded with caution, as respondents may have been more inclined towards reporting a positive change, given the illegal nature of this activity. Our results also point to Santiago as the main sink of marine turtle meat sourced on Boa Vista; this was evidenced by the shift from subsistence to commercial harvesting on Boa Vista, possibly driven by the increasing demand for turtle meat in the expanding urban area of Sal Rei (Boa Vista) and the city of Praia (Santiago), as suggested by some respondents, reflecting a pattern reported in previous studies (Araújo, 2008; Merino et al., 2008). Nevertheless, to minimize potential survey biases, specialized questioning techniques developed in the social sciences for making it impossible to link incriminating data to an individual might have been better suited for our investigation (Nuno \& St. John, 2015).

The biological impact of the trade in marine turtle products in Cape Verde was underestimated previously, as mortality data were limited to the harvesting of reproductive females on the main nesting beaches; estimates indicate a poaching rate of $5 \%$ of the 8,900 reproductive females estimated to have nested on Boa Vista in 2009 alone (Marco et al., 2012). We recognize the impact of the harvest on the nesting beaches but suggest that added pressure from opportunistic captures at sea needs to be considered. The potential impact on population demography is difficult to ascertain, as unknown numbers of males and juveniles are targeted at sea. Our estimated magnitude of harvest should be regarded as conservative, as some respondents may have been reluctant to share information about illegal activities, and using the snowball sampling technique we may have identified only a small and possibly non-representative number of harvesters and sellers. There is a need for further quantitative investigation of illegal harvesting and trade, in conjunction with the impact of incidental captures at sea (Martins et al., 2008; Melo \& Melo, 2013). Barriers to this include the lack of adequate law enforcement and surveillance at sea and on land, making trade relatively easy and generally unnoticed, and thus difficult to assess. Knowledge of the specifics of wildlife trade dynamics, such as transport mechanisms and routes within and between islands, is essential to develop practical, policy-relevant measures (TRAFFIC, 2008). These dynamics could be explored further using other types of data and specialized questioning techniques (Nuno et al., 2013). Nevertheless, we have contributed to identifying key factors and potential processes that require further exploration, for example by focusing 


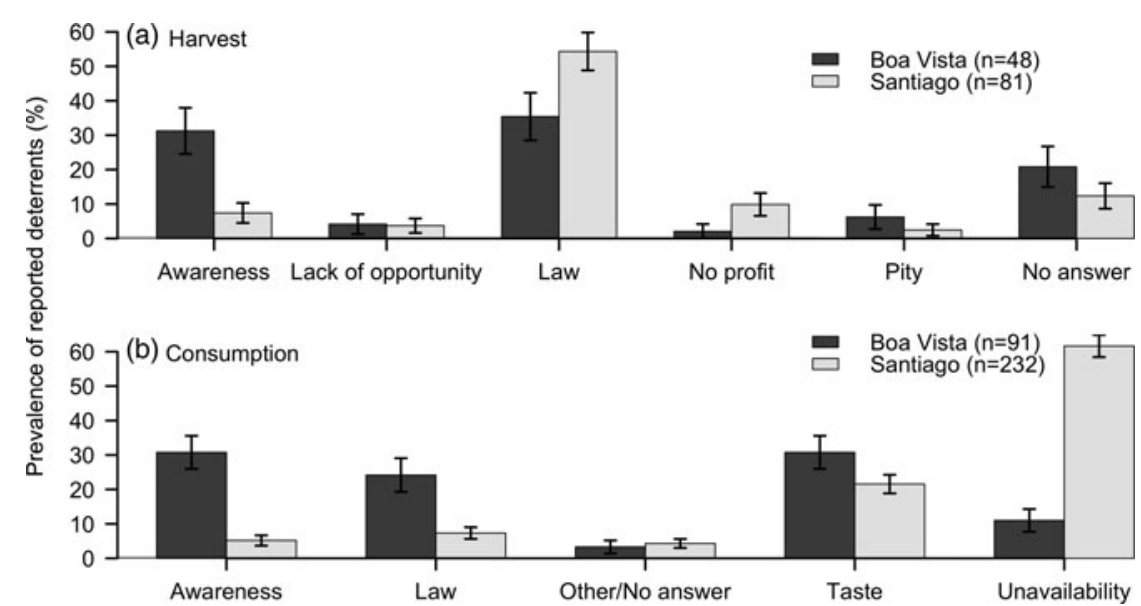

FIG. 6 The perceived deterrents against (a) harvesting or selling marine turtles or their products (reported by fishers and fish sellers) and (b) consumption of marine turtle products (reported by the general public) on Boa Vista and Santiago (Fig. 1). (Each respondent could provide multiple answers.) on understanding causation between behavioural and conservation outcomes and potential predictor variables related to individual socio-economic characteristics and the implementation of multiple conservation interventions.

\section{Exploratory assessment of conservation interventions}

The Cape Verde government and NGOs have focused on two lines of action to discourage harvesting and consumption of marine turtles: (1) providing a legal framework for turtle protection in parallel with enforcing deterrents at the nesting beaches; and (2) awareness-raising campaigns to motivate consumers to change their behaviours regarding the consumption of turtle products (Araújo, 2008). Interventions are believed to have been at least partially successful but our results also draw attention to several limitations or gaps in some of the areas of intervention, and provide an opportunity to develop new strategies and inform discussions about potential changes in national regulations for marine turtle protection.

\section{Laws and regulations}

Our findings suggest that legal and regulatory measures exert an important influence on people's participation in harvesting and trade of marine turtles, and therefore the development of the laws and regulations on Cape Verde may be an effective mechanism for reducing illegal trade. However, the effectiveness of the enforcement of deterrents appears to be undermined by gaps and weaknesses in specific parts of the enforcement process, as experienced elsewhere (e.g. Bräutigam \& Eckert, 2006; Keane et al., 2008; TRAFFIC, 2008). This is evidenced by the reported increase in harvesting of marine turtles on protected beaches after military presence was withdrawn in 2014 as a result of conflicts with the local communities on Boa Vista (Fonseca, 2014), which suggests that despite the widespread knowledge that harvesting of marine turtles is illegal, people will generally not comply voluntarily, and therefore the protection of marine turtles requires effective enforcement. The problem may stem from limited means and resources, both financial and human, a lack of information about the law, and difficulties in interpreting it, and limited availability of specialized training, especially in conflict mediation (Araújo, 2008; Merino et al., 2008). It is thus essential that law enforcement mechanisms and resources are improved and that policies and controls are targeted at points in the trade chain where they are likely to have the greatest impact. Although some efforts have been made in Santiago to tackle the problem (Araújo, 2008), ongoing harvesting and the lack of government involvement in surveillance activities indicate there is a need to strengthen the institutions of the judicial sector (e.g. law enforcement agencies, ministries and environmental authorities), improve understanding among policy makers of the significance of illegal and unsustainable wildlife trade, and focus on the development of multiagency law enforcement capacity (Akella \& Cannon, 2004; TRAFFIC, 2008). Most law enforcement and beach protection in the study area has been provided by NGOs (to date, all led by foreigners), including community-based organizations; however, although this non-governmental investment is generally viewed as positive, there is a need to recognize the essential, fundamental role of government and the need for governments to engage politically, logistically and financially to sustain initiatives in the long term (Bräutigam \& Eckert, 2006).

\section{Awareness}

To evaluate the impact of awareness campaigns the key questions are whether such messaging reaches its target audiences, whether it affects their attitudes and ultimately whether it influences their consumptive behaviour. Our results indicate that awareness-raising efforts on both islands may have been successful in increasing people's awareness of the illegality of the trade in marine turtles; however, 
there was still a lack of knowledge regarding the negative impacts of the consumption of turtle products and the illegality of turtle consumption (although people were generally aware that harvesting was illegal). The majority of consumers did not fully understand the connection between their consumptive habits and the illegal trade of marine turtles. Suppliers of marine turtle meat reported that there had been a decrease in demand; however, a high percentage of the respondents admitted that their level of consumption was related to the availability of turtle meat. This suggests there is a lack of understanding of the links between raising awareness and changes in the attitudes and behaviour of participants in the wildlife trade. Thus, the biggest challenge may be to develop an awareness campaign targeted primarily at consumers. Nevertheless, some positive results have been observed on Boa Vista, where improved awareness has been one of the reported drivers for the reduction in consumption of marine turtles. For optimum results, awareness campaigns should incorporate a monitoring and evaluation component, promoting science-based management (Pullin et al., 2004; Sutherland et al., 2004).

As on other islands in Cape Verde (Merino et al., 2008), harvesting and sale of marine turtles provide an alternative source of income for fishers' families on the study islands, especially on Santiago. The effects of any further deterrence on the harvest of female turtles on these islands is a key issue for future study. The non-consumptive use of turtles, for example in tourism, may be more profitable (Tisdell \& Wilson, 2001; Troëng \& Drews, 2004), and this is an important and developing sector for Cape Verde (Merino \& Berrow, 2006), with turtle-watching generating up to EUR 100,000 per year on Boa Vista alone, distributed among tourism agencies, nature guides, and research and conservation activities (P. Lopez, pers. comm., September 2012). However, the effectiveness and fairness of turtle-based tourism in generating income for local communities in the study area remains to be assessed. In addition, the low number of nesting turtles on Santiago and the low likelihood of observing turtles regularly at sea render this option unviable on Santiago, and may in fact promote the opportunistic harvesting of marine turtles by Santiago fishers on other islands. At the time of the study the sale of a single turtle generated up to CVE 20,000, which is the equivalent of a month's salary for at least $25 \%$ of the fishers interviewed in Santiago. The challenge on Santiago, therefore, lies in the fact that the sale of marine turtles can generate high returns, and as the meat is easy to store and transport, it is tempting for fishers to harvest turtles to gain extra income, as recorded elsewhere (Duffy et al., 2016). This illegal trade is further exacerbated if no financial aid is offered to fishers in times of socio-economic decline; therefore, participatory research of alternative sources of income may be important, and efforts to improve living and working conditions should be developed, as has been done for other islands in the archipelago (Merino et al., 2008) and elsewhere (Brown, 1998; Campbell \& Vainio-Mattila, 2003).

\section{Conclusion}

Our results highlight the gaps in addressing the problem of illegal trade of marine turtles in Cape Verde and indicate future challenges that may arise. There is evidence that marine turtles are still being harvested and consumed, and therefore conservation interventions need to be refined and reassessed.

The trade and consumption of marine turtles in Cape Verde not only threatens the species in question but also the health of the ecosystems in which they occur, as well as reducing the availability of turtles for the development of alternative, non-consumptive uses such as turtlewatching. It is clear that conservation research needs to be integrated with social and economic disciplines to gain a full understanding of the spatial, temporal and social aspects of the consumption of marine turtles in Cape Verde.

\section{Acknowledgements}

This research was undertaken for Turtle Foundation in collaboration with Cape Verde's National Fisheries Development Institute (INDP), and received financial support from Turtle Foundation and the University of Exeter. JMH would like to thank her colleagues at Turtle Foundation in Sal Rei, Christian Roder and Julio Rocha; Bernardo Gonçalves for conducting a great part of the interviews, often in difficult conditions and places; Carlos Santos, Vera Gominho, Alcides Varela, Victor Tavares, Paulo Varela, Avelino Tavares, Anselmo Rocha, Osvaldinha Rosa and Melicia Cardoso of INDP for logistical support; Jelena Adeli and Indira for making life in Santiago so much easier; Christophe Eizaguirre and Gail Schofield for their help with analysis, review and editing of the manuscript; Peter Richardson and Amdeep Sanghera of the Marine Conservation Society for valuable input on the initial questionnaire, and sharing their experiences of the Turtles in the Caribbean Overseas Territories project. BJG and AN acknowledge the support of the Darwin Initiative. We thank the reviewers for their valuable comments.

\section{References}

Akella, A.S. \& CAnnon, J.B. (2004) Strengthening the Weakest Links: Strategies for Improving the Enforcement of Environmental Laws Globally. Center for Conservation and Government, Conservation International, Washington, DC, USA.

Araújo, S. (2008) Relatório da Campanha Nacional para a Conservação das Tartarugas Marinhas em Cabo Verde. Direcção Geral do Ambiente, Praia, Cape Verde. 
Baum, J.K., Myers, R.A., Kehler, D.G., Worm, B., Harley, S.J. \& Doherty, P.A. (2003) Collapse and conservation of shark populations in the Northwest Atlantic. Science, 299, 389-392.

Boletim Oficial da República de Cabo Verde (2005) Resolução $n^{\circ} 3 / 2005$, de 21 de Fevereiro de 2005 que aprova o Plano de Gestão dos Recursos da Pesca.

Boletim Oficial da República de Cabo Verde (2010) Decreto-lei $n^{\circ} 7 / 2002$ de 30 de Dezembro. Que estabelece as medidas de conservação e protecção das espécies vegetais e animais ameaçadas de extinção, $I$ - serie, $n^{\circ} 48$.

Bräutigam, A. \& Eckert, K.L. (2006) Turning the Tide: Exploitation, Trade and Management of Marine Turtles in the Lesser Antilles, Central America, Colombia and Venezuela. TRAFFIC International, Cambridge, UK.

Brown, D. (1998) Participatory Biodiversity Conservation. Rethinking the Strategy in the Low Tourist Potential Areas of Tropical Africa. Natural Resource Perspectives. Overseas Development Institute, London, UK.

Campbell, L.M. \& Vainio-Mattila, A. (2003) Participatory development and community-based conservation: opportunities missed for lessons learned? Human Ecology, 31, 417-437.

Cozens, J., Renon, B. \& Gonçalves, E. (2012) Campaign report. ADTMA SOS Tartarugas, Cape Verde.

Duffy, R., St John, F.A.V., Büscher, B. \& Brockington, D. (2016) Toward a new understanding of the links between poverty and illegal wildlife hunting. Conservation Biology, 30, 14-22.

FonseCA, S. (2014) 19 tartarugas mortas nas praias da Boa Vista. A Semana. Http://www.asemana.publ.cv/spip.php?article102115 [accessed 29 September 2015].

Garnett, S.T., SAyer, J. \& DU Toit, J. (2007) Improving the effectiveness of interventions to balance conservation and development: a conceptual framework. Ecology and Society, 12, 2.

INE (Instituto Nacional de Estatística) (2010) $I v^{\circ}$ Recenseamento Geral da População e Habitação. Instituto Nacional de Estatística de Cabo Verde, Praia, Cape Verde.

Jackson, J.B.C., Kirby, M.X., Berger, W.H., Bjorndal, K.A., Botsford, L.W., Bourque, B.J. et al. (2001) Historical overfishing and the recent collapse of coastal ecosystems. Science, 293, 629-637.

Keane, A., Jones, J.P.G., Edwards-Jones, G. \& Milner-Gulland, E.J. (2008) The sleeping policeman: understanding issues of enforcement and compliance in conservation. Animal Conservation, $11,75-82$.

LÓpez-Jurado, L.F. (2007) Historical review of the archipelagos of Macaronesia and the marine turtles. In Marine Turtles. Recovery of Extinct Populations (eds L.F. López-Jurado \& A. Liria), pp. 53-76. Instituto Canario de Ciencias Marinas, Las Palmas, Spain.

Loureiro, N.S. \& Torrão, M.M.F. (2008) Homens e tartarugas marinhas: Seis séculos de história e histórias nas ilhas de Cabo Verde. Anais de História de Além-Mar, 9, 37-78.

Marco, A., Abella, E., Liria-Loza, A., Martins, S., López, O., JIMÉNEZ-BORDÓN, S. et al. (2012) Abundance and exploitation of loggerhead turtles nesting in Boa Vista island, Cape Verde: the only substantial rookery in the eastern Atlantic. Animal Conservation, 15, 351-360.

Marco, A., Pérez, E.A., Monzón Argúello, C., Martins, S., Araújo, S. \& López-Jurado, L.F. (2011) The international importance of the archipelago of Cape Verde for marine turtles, in particular the loggerhead turtle Caretta caretta. Zoologia Caboverdiana, 2, 1-11.

Martins, S., Monteiro, R., Abella, E., Abu-Raia, M., Marco, A. \& López-Jurado, L.F. (2008) Prospective analysis about the impact of artisanal fishing, artisanal bycatch and illegal trade over loggerheads in Cape Verde islands. In Proceedings of the 32nd
Symposium on Sea Turtle Biology and Conservation. Huatulco, Mexico.

Melo, J. \& Melo, T. (2013) Interviews with fishers suggest European longlining threatens sea turtle populations in Cape Verdean waters. Marine Turtle Newsletter, 138, 18-19.

Merino, S.E. \& Berrow, S. (2006) Marine eco-tourism in Cape Verde: its potential for sustainable development and conservation of marine biodiversity. Occasional Publication of the Irish Biogeographical Society, 9, 199-206.

Merino, S.E., Correia, S.M., Castillo, M.D., Quensiére, J. \& VANDERLINDEN, J.P. (2008) Community-based conservation of marine turtles: its contribution to coastal resources management in islands to the northwest of Barlavento, Cape Verde. In Proceedings of the VIIth Extraordinary Meeting of the Scientific Committee. INDP, Praia, Cape Verde.

Nietschmann, B. (1995) The cultural context of sea turtle subsistence hunting in the Caribbean and problems caused by commercial exploitation. In Biology and Conservation of Sea Turtles (ed. K.A. Bjorndal), pp. 439-445. Smithsonian Institution Press, Washington, DC, USA.

Nuno, A., Bunnefeld, N. \& Milner-Gulland, E.J. (2014) Managing social-ecological systems under uncertainty: implementation in the real world. Ecology and Society, $19,52$.

Nuno, A., Bunnefeld, N., Naiman, L.C. \& Milner-Gulland, E.J. (2013) A novel approach to assessing the prevalence and drivers of illegal bushmeat hunting in the Serengeti. Conservation Biology, 27, 1355-1365.

Nuno, A. \& S T. John, F.A.V. (2015) How to ask sensitive questions in conservation: a review of specialized questioning techniques. Biological Conservation, 189, 5-15.

Parsons, J.J. (1962) The Green Turtle and Man. University of Florida Press, Gainesville, USA.

Polidoro, B.A., Livingstone, S.R., Carpenter, K.E., Hutchinson, B., Mast, R.B., Pilcher, N. et al. (2008) Status of the world's marine species. In The 2008 Review of The IUCN Red List of Threatened Species (eds J.-C. Vié, C. Hilton-Taylor \& S.N. Stuart). IUCN, Gland, Switzerland.

Pollnac, R., Christie, P., Cinner, J.E., Dalton, T., Daw, T.M., Forrester, G.E. et al. (2010) Marine reserves as linked socialecological systems. Proceedings of the National Academy of Sciences of the United States of America, 107, 18262-18265.

Pullin, A.S., Knight, T.M., Stone, D.A. \& Charman, K. (2004) Do conservation managers use scientific evidence to support their decision-making? Biological Conservation, 119, 245-252.

R Development Core Team (2009) R: A Language and Environment for Statistical Computing. R Foundation for Statistical Computing, Vienna, Austria.

Raymond, C.M. \& Knight, A.T. (2013) Applying social research techniques to improve the effectiveness of conservation planning. BioScience, 63, 320-321.

Roe, D., Mulliken, T., Milledge, S., Mremi, J., Mosha, S. \& Grieg-Gran, M. (2002) Making a Killing or Making a Living? Wildlife Trade, Trade Controls and Rural Livelihoods. IIED, London, UK, \& TRAFFIC, Cambridge, UK.

Rowcliffe, J.M., De Merode, E. \& Cowlishaw, G. (2004) Do wildlife laws work? Species protection and the application of a prey choice model to poaching decisions. Proceedings of the Royal Society $B, 271,2631-2636$.

Springer, A.M., Estes, J.A., van Vliet, G.B., Williams, T.M., DoAk, D.F., Danner, E.M. et al. (2003) Sequential megafaunal collapse in the North Pacific Ocean: an ongoing legacy of industrial whaling? Proceedings of the National Academy of Sciences of the United States of America, 100, 12223-12228. 
St. John, F.A., Keane, A.M. \& Milner-Gulland, E.J. (2013) Effective conservation depends upon understanding human behaviour. In Key Topics in Conservation Biology 2 (eds D.W. Macdonald \& K.J. Willis), pp. 344-361. John Wiley \& Sons, Chichester, UK.

Sutherland, W.J., Pullin, A.S., Dolman, P.M. \& Knight, T.M. (2004) The need for evidence-based conservation. Trends in Ecology and Evolution, 19, 305-308.

The World B ANK (2012) World Development Indicators. Http://data. worldbank.org/data-catalog/world-development-indicators [accessed 25 March 2015].

Tisdell, C. \& Wilson, C. (2001) Wildlife-based tourism and increased support for nature conservation financially and otherwise: evidence from sea turtle ecotourism at Mon Repos. Tourism Economics, 7, 233-249.

TRAFFIC (2008) What's Driving the Wildlife Trade? A Review of Expert Opinion on Economic and Social Drivers of the Wildlife Trade and Trade Control Efforts in Cambodia, Indonesia, Lao PDR and Vietnam. East Asia and Pacific Region Sustainable Development Discussion Papers. East Asia and Pacific Region Sustainable Development Department, World Bank, Washington, DC, USA.
Troëng, S. \& Drews, C. (2004) Money Talks: Economic Aspects of Marine Turtle Use and Conservation. WWF-International, Gland, Switzerland.

Witherington, B.E. \& Frazer, N.B. (2003) Social and economic aspects of sea turtle conservation. In The Biology of Sea Turtles Volume II (eds P.L. Lutz, J.A. Musick \& J. Wyneken), pp. 355-384. CRC Press, Boca Raton, USA.

World Health Organization (2010) World Health Statistics 2010. World Health Organization, Geneva, Switzerland.

\section{Biographical sketches}

JOANA M. HANCOCK is a biologist interested in conservation research on marine turtles of West Africa. SAFIRO FURTADO was a research assistant for loggerhead turtle conservation projects on Boa Vista and Santiago islands (deceased July 2012). Sonia MERINo is the National Director of Research and Education in El Salvador and has extensive experience in fisheries management. BRENDAN J. GODLEY is a conservation scientist who specializes in marine vertebrates. ANA NunO's research focuses on understanding social-ecological interactions to support more effective conservation interventions. 